\title{
Hearing Things
}

\section{Music and Sounds the Traveller Heard and Didn't Hear on the Grand Tour}

VANessa AgneW

UNIVERSITY OF MICHIGAN

Let us begin our sonic grand tour in a northern European city. By convention this was London, but by the late eighteenth century the point of embarkation could have been a provincial English town or a city in Thuringia, equally. Travellers felt the pull of the open road, the lure of the south, the authority of history, the rejuvenating spark of antique culture. The journey was fraught with discomfort and danger-bad roads, uncomfortable inns, bandits; it was also expensive, tiring and potentially lonely. Yet, in the person of Johann Wolfgang von Goethe (1749-1832) we find an assured and informative travelling companion. His purpose was not explicitly the pursuit of Italian music, but we find in him an incidental commentator on the unfolding soundscape. ${ }^{1}$ This soundscape included concerts, operas, church and street music; it also included conversation, so fundamental to sociability in the eighteenth century and to Goethe's own intellectual modus operandi. The soundscape extended, too, to the contrasting sounds of urban and country life, unsought auditory experiences, and the noises produced by travel itself. We can thus accompany Goethe to examine what the traveller heard and did not hear-a soundscape that was richer than organised music making and conversing, one that 
was both aleatoric and cacophonic. Via Goethe's Italian Journey (published in 1816), we establish the centrality of sound to the grand tour-little remarked on in the scholarly literature-as well as sound's imbrication in other modes of cultural appreciation and in alternative forms of knowledge making. ${ }^{2}$ Since sound and music were central to the eighteenth-century traveller's experience, it will be argued that there is something to be learned by examining the types of auditory experience sought out by the traveller, as well as from the auditory experiences elaborated, imagined or elided in travellers' accounts of their journeys. Finally, this article raises questions about what it meant to listen in the eighteenth century and, by implication, asks what it means for us, in the present, to listen to the past and so participate in a broad and thickly described cultural history of sound and music.

As generations of rich young men had done before him, Goethe set off for Italy in 1786 in the expectation that the journey would open new vistas. Exposed, at last, to the heritage of classical antiquity, he would finally enjoy that which lent menand increasingly women-a degree of urbanity and self-assuredness. The grand tour was a journey that consolidated familial and social ties, opened commercial possibilities, launched artistic careers and marked the start of adult life. ${ }^{3}$ Of course, Goethe was no longer a boy. At thirty-seven, he was known throughout Europe for his Sturm und Drang novella, Die Leiden des jungen Werther (1774); he had been appointed Privy Councillor by Duke Carl August, and recently ennobled. With considerable professional responsibilities, he somehow found time for a lively creative and social life. Still, Weimar was not Paris or Rome and he longed for something more. As the carriage took him away from the pinching court, secure in his assumed identity he felt the clouds lift, the vegetation luxuriate and the landscape grow picturesque.

The journey would be Goethe's making as a man of science. The intensity of the Mediterranean light prompted an investigation of colour and its perception, resulting in a vast treatise on colour theory that Goethe later deemed his best work. He stopped often to geologise and to botanise and, with Linnaeus in his pocket, was constantly on the look out for new plants. As he wrote to his friend Johann Gottfried Herder, he sought the very essence of 'plantness', the archetypal Urpflanze that would enable all plants to be recognised as plants. ${ }^{4}$ On a more prosaic note, Goethe looked forward to eating grapes and tasting his first fig. ${ }^{5}$ In Palermo he toured the 
public gardens, so perfect in their layout and botanical variety that they invoked the garden of Alcinous, the superabundant garden in Homer's Odyssey. ${ }^{6}$

Amid the sensory proliferation that was Goethe's tour, there was also music. Close to home, he attended an opera and remarked on the skill of the Jesuit organ builders in Regensburg.7 A girl walking with her father by the side of the road joined Goethe in his carriage and he was charmed by her musicality and naïve curiosity. The strings of the girl's harp served as a kind of weather barometer, going flat whenever it rained. On this leg of the journey, the instrument sounded sharp-a happy omen for Goethe and his companion. ${ }^{8}$ Further south, Goethe remarked on music making at a local market. The square was piled high with fruit and vegetables; the people were constantly shouting, throwing things, laughing and singing. It was the mild climate and cheap food, he said, that made life voluble as one ventured closer to the Tropic of Cancer. By night the peasants' music making grew louder still. They sang satirical ballads about the Seven Years War, played the violin and dulcimer in the street, and whistled and imitated birdcalls. ${ }^{9}$ In Venice, Goethe was charmed by gondolieri singing verses by Tasso and Ariosto to their own melodies.

Such commentary suggests that whatever might be asserted about Goethe's limited musicality, the self-described 'fugitive from the north' was indeed alive to sound as he journeyed through Italy. ${ }^{10}$ In this, Goethe was like any number of other travellers who left northern cities on an established trek south. Following an itinerary that took them from London to Paris, then to Italy-Genoa, Venice, Florence and on to Rome and Naples-these grand tourists finally circled home through the German states. The more intrepid took in countries farther to the north and east-Scandinavia, the Ottoman Empire, Egypt and the Holy Lands. By the early nineteenth century, Greece-the acknowledged cradle of Western civilisation and a part of the Ottoman Empire until 1821-had been added to the itinerary. Accompanied by a guide or cicerone, travellers were informed about where to stay and what to see. Their experiences were regulated by guidebooks, which instructed them on proper travel etiquette, and by sets of instructions known as apodemics, which helped the traveller make sense of the unfamiliar and gave them a basis upon which to make national comparisons-the socially adroit French, the serious, reflective Germans.11 Thomas Nugent's widely read four-volume work (published in 1749 and numerous subsequent editions) gives some indication of what the reader 
was to expect: the work has the capacious title, The Grand Tour. Containing an Exact Description of most of the Cities, Towns, and Remarkable Places of Europe. Together with a Distinct Account of the Post-Roads and Stages, with their respective Distances, Through Holland, Flanders, Germany, Denmark, Sweden, Russia, Poland, Italy, France, Spain, and Portugal. Likewise Directions relating to the Manner and Expence of Travelling from one Place and Country to another. As also Occasional Remarks on the Present State of Trade, as well as of the Liberal Arts and Sciences, in each respective Country. Collectively, apodemics helped ensure that travellers on the grand tour were exposed to a common cultural corpus, and, via the work of architects and designers like Inigo Jones and Robert Adam, they helped established classical art and architecture as a model for domestic styles.

For all grand tourists, experience was thus central. Committed to a Lockean belief in the epistemological value of sensory experience, travellers felt themselves superior to stay-at-homes, whose learning was confined to hearsay and to the book. Charles Burney (1726-1814) reminded the reader of this fact when he appropriated the opening gambit of all eighteenth-century travelogues to insist on the superiority of witnessing: to make reliable knowledge about music, he insisted, meant leaving the comfort and security of one's own hearth and travelling to the source. This had been the custom in antiquity, with the great historian-travellers like Herodotus and Asclepiades, who was said to have toured the world on a cow's back, living on its milk; and it was a practice-travelling-that Burney meant to emulate.12 For Burney, as for so many of his historian contemporaries, knowledge about music was contingent on seeing and hearing things for oneself, on the credibility of the witness, on collecting authentic artefacts, and on visiting what came to be referred to as the 'showplaces of history'.13 By applying a standard rhetorical device to musical travel, Burney pioneered a new concept: the eyewitness was transformed into an earwitness, one who testified to the subjective aural experience of travel.

Music was not formally incorporated into these eighteenth-century apodemics and yet many travellers-musicians as well as non-musicians-travelled in the expectation that musical experiences would be integral to their mobile education. And it is thanks to such travel reports that we have inherited a vivid record of eighteenth-century music making, written with the fresh eye and ear of the outsider-Joseph Addison's Remarks on Several Parts of Italy (1705); Burney's 
Musical Tours through France and Italy (1770), and the Lowlands and the German states (1772); Susan Burney's lively record; and that, too, of Hester Lynch Piozzi (Observations and Reflections, 1789).

Because of the greater availability of digitised eighteenth-century source material, but also because of developments within musicology that signal a growing enthusiasm for cultural historical and sociological approaches to the study of music, there is new scholarly interest in what might be thought of as the historical soundscape. Increasingly, scholars are interested in travel's contribution to the cultural history of music and, conversely, the role of music and sound in the history of travel, cross-cultural encounters, colonial practice, anthropological and racial thought, and emerging national and transnational identities. ${ }^{14}$ And yet, in writing about the sonic dimensions of travel, we are confronted with problems of terminology. Shall we refer to it as musical travel? Music of or on the grand tour? The soundscape encountered by travellers on the grand tour? To refer to music and sound on the grand tour implies that aural phenomena were ancillary to the main business of travel. Yet we know that music and sound were commented on frequently by eighteenth-century travellers. Indeed, for some travellers the lure of Continental music was so strong as to be a motivating force behind the journey itself. By the same token, we cannot speak of music on the grand tour in unitary terms: music did not constitute a single national tradition nor a series of national traditions; moreover, the traveller's appreciation of music was not confined to serious music, nor even to modern music. At best, we can say that with some few exceptions-including Burney and Johann Friedrich Reichardt-most eighteenthcentury travel commentary on music and sound was haphazard and digressive; it was interspersed with personal reflections and it contributed to a broader picture of social and cultural life.

Here, we mark sound's difference from other cultural objects. On the grand tour, classical sculpture, painting and architecture constituted a recognised and recognisable cultural corpus in which the well-healed traveller was meant to gain fluency. In Rome, the traveller expected to spend some time appreciating the Coliseum and the Pantheon; in Herculaneum, he would be led into the dark, halfexcavated depths of the ancient ruins to inspect titillating wall paintings; in recently discovered Pompeii, he could marvel at time frozen beneath a layer of ash and 
rubble; in Naples, he might play the lotto and sample the macaroni. ${ }^{15}$ Music, in contrast, was always a more contested discursive site. To be sure, there were important destinations like the Parisian and Neapolitan operas and, for the betterconnected, meetings with famous composers and performers. But by the end of the eighteenth century there was still no real consensus about the relative merits of French and Italian music, nor about the superiority of vocal over instrumental music. ${ }^{16}$ Perhaps most importantly, music lacked the classical imprimatur enjoyed by painting, sculpture and architecture. As Burney would complain while preparing his General History of Music, too little was known about the music of antiquity and what was known suggested too few similarities with music in the present. ${ }^{17}$

Answering the question, 'What did the grand tourist hear?' is more difficult than might be assumed. Travellers listened to whatever was available: they heard organised music making in churches, concert rooms, pleasure gardens and opera houses, but they also listened to impromptu musicking in marketplaces, on the streets and in the fields. Thus, while Burney might have been adopting a common titular convention when he referred to his musical travelogues in terms of the Present State of Music, the books are in fact perfectly described. What constituted the 'present state of music' was an eclectic mix of old and new, of high and low, of sounds and of noise. Since scholars like Wolfgang Gratzer have drawn our attention to the need for a more expansive account of the history of listening, we might consider the question of how the eighteenth-century traveller made sense of such unfamiliar soundscapes. ${ }^{18}$ By extension, we can draw some conclusions about the ways in which travel accounts may be used to help construct a cultural history of listening that includes not only the music of Scarlatti, Jommelli and Sammartini, but also the music and the sounds that constituted a sonic backdrop for the grand tourist.

In some sense, the grand tour set up the traveller for disappointment. This was certainly the case for the English aristocrat William Beckford, who remarked on Antwerp's deadly silence and contrasted it with the 'important bustle' that had once made the city so famous. ${ }^{19}$ For our own travelling companion, Goethe, comparing his observations with the reports of earlier travellers and the present with its classical antecedents also implied a falling off from the original. His initial enthusiasm about the botanical gardens in Palermo, for instance, gave way to disappointment and 
frustration when he found himself unable to reconcile the Sicilian flora either with the idealised Homeric description or with the Linnaean classificatory system. 'Gone were my fine poetic resolutions - the garden of Alcinous had vanished and a garden of the natural world had appeared in its stead.'20 And, much as Goethe criticised Newton for his explanation of the frangibility of light, he took Linné to task for his reductionist approach to nature. 'Why', Goethe asked in Faustian fashion, 'are we moderns so distracted, why do we let ourselves be challenged by problems which we can neither face nor solve!'21

We find a similar, if less explicitly reflected, gesture in Goethe's assessment of music. ${ }^{22}$ Joseph Addison, writing in the first years of the century, had established a form of auditory horizon for later travellers, describing:

a custom at Venice, which they tell me is particular to the common people of this country, of singing stanzas out of Tasso. They are set to a pretty solemn tune, and when one begins in any part of the Poet, it is odd but he will be answered by some body else that overhears him: So that sometimes you have ten or a dozen in the neighbourhood of one another, taking verse after verse, and running on with the poem as far as their memories will carry them. ${ }^{23}$

Readers of travel writing thus knew what to expect of Venetian music. In The Confessions it was the gondoliers' singing that, Rousseau claimed, converted him to Italian music. 'I had brought with me from Paris', he wrote, 'the prejudice of that city against Italian music but I had also received from nature a sensibility and niceness of distinction that prejudice cannot withstand ... In listening to barcarolles, I found I had not yet known what singing was.'24 Rousseau defined barcarolles in his Dictionary of Music (1767) as:

A type of song in the Venetian dialect that the gondoliers in Venice sing. Although the airs are made for the people, and are often composed by the gondoliers themselves, they are so melodious and charming that there is not a musician in the whole of Italy who doesn't pique himself on knowing and singing them.

The gondolieri apparently knew Tasso's epic poem 'Jerusalem Delivered' by heart and, according to Rousseau, sang alternate stanzas from boat to boat. ${ }^{25}$ 
To hear the gondolieri sing was, in other words, to hear what previous travellers had heard or claimed to have heard. It was also to confirm the existence of an ancient, unbroken tradition of indigenous music making in which simple boatmen intoned classical texts; it was to uphold the ideal of Venetian musicality and, in a Rousseauvian sense, it was to revisit prelapsarian music making at its very source. ${ }^{26}$ But, as Goethe noted, gondolieri performances were now largely a thing of the past and there were no guarantees that travellers could still hear the lovely sounds that earlier travellers seem to have enjoyed. ${ }^{27}$ Motivated by the desire for a complete sensory experience of Venice, Goethe commissioned a gondolieri performance and, sitting in a boat, he became audience to the experience made famous by Joseph Addison, Rousseau and others before them. 'If the listener chooses the right spot, which is half way between the [gondolieri] ... the more enchanting the singing is', Goethe wrote. 'The sound of their voices far away was extraordinary', he went on, 'a lament without sadness, and I was moved to tears.'28 Here, Goethe reported that women on the Lido sang while they awaited the fishermen's return. While there is no indication that Goethe actually heard the women singing on the Lido, he observed that the sound of their voices across the water, answered by the returning men, was like the 'singing of a lonely human being sent out into the wide world till it reached the ears of another lonely human being who [was] moved to answer it'.29 Other travellers experienced similar anxiety over what they might fail to hear. Hester Piozzi, for example, wondered aloud whether the gondolieri would ever sing and was gratified when, finally, she did hear the boatmen calling across the Grand Canal. It was, she said, a pretty, pleasing song about the flight of Erminia from Tasso's 'Jerusalem'.30 For Burney, the songs of the gondolieri were invoked in The General History of Music as a foil for the composer Jommeli, whom he met in 1770, and whose 'learned and ingenious music' Burney deemed insufficiently appreciated by the 'frivolous and depraved taste' of the Italians who preferred simple airs and barcaroles. ${ }^{31}$

There were yet other musical experiences that Goethe and fellow grand tourists deliberately sought out. ${ }^{32}$ In Naples, Goethe's travel journal has him listening, for example, to the tarantella, a dance performed by two women to the accompaniment of castanets and the tambourine. 33 This energetic dance in compound time, sometimes played for as long as several hours, had long been suggested as a cure for 
tarantism, a disorder said to be caused by the bite of the tarantula spider. With symptoms that reportedly included mania, convulsions and even death, tarantism had been commented on for centuries. By the end of the eighteenth century foreign travellers were curious to ascertain for themselves whether tarantism actually existed and, if so, whether music could affect a cure.

In 1753, The Gentlemen's Magazine published a letter that seemed to offer proof of music's efficacy in treating the disorder. The letter included a transcription and, apparently, a firsthand account by the father of the English composer Stephen Storace. ${ }^{34}$ Storace reported that he had been visiting his hometown near Naples when he saw a man slump to the ground after being bitten by a tarantula. The man seemed close to death and, with neither doctor nor priest available, Storace was asked to play: he tried various pieces without success, then an old woman was fetched to teach him the antidotal tune. Within a few minutes Storace said he had learned enough to begin playing. The result, he said, was instantaneous: the tarantus leap to his feet and began moving every joint of his body. When Storace stopped playing, the victim collapsed, screamed, contorted his limbs and face, and scraped the ground with his hands. When he recommenced, the victim resumed his frenetic dance. According to Storace, the dance resembled a very wild jumping without 'rules or manners', and was not unlike the 'Chinese dances sometimes seen on the stage'. Hour upon hour, faster and faster the music went on until Storace, too, was on the verge of collapse. Finally, the victim was given a sword with which to bleed his hands and feet. Victim and violinist collapsed, exhausted. According to the account, the man was bled some more, given a strong cordial and left to sleep for several hours, whereupon he woke, perfectly recovered.

Many foreigner travellers found such reports apocryphal. Some, like A.F. Büsching, went so far as to lampoon Storace's claims to have treated tarantism. 'Had [Storace] not had a violin on him but rather a good Spanish cane and let the back of this beggar soundly feel its power, he would have cured him a lot faster than in two hours', wrote Büsching in a 1755 article published in Hamburgisches Magazin. 35 Burney's Italian informants told him much the same when he inquired about the practice during his 1770 visit to Naples. 'The whole thing is an imposition', a Doctor Sarao informed Burney, 'practiced by the people of Apulia, to gain money: not only the cure but the malady itself is a fraud.' 36 Burney investigated tarantism further 
when he visited Potsdam two years later. Although a great music enthusiast and a believer in music's curative powers, Burney's informant was doubtful: music might be able to cure ailments like insomnia and melancholy, but he suspected that the tarantella was a Neapolitan fabrication.

Notwithstanding this kind of scepticism, travellers to southern Italy expected, or were expected to report on, the tarantella. ${ }^{37}$ This reflects the widespread English enthusiasm for Italian folk customs, as reflected in a painting of Lady Hamilton, second wife of the British Envoy to Naples, famous for her tableaux vivant and for dancing the tarantella (see Figure 1).

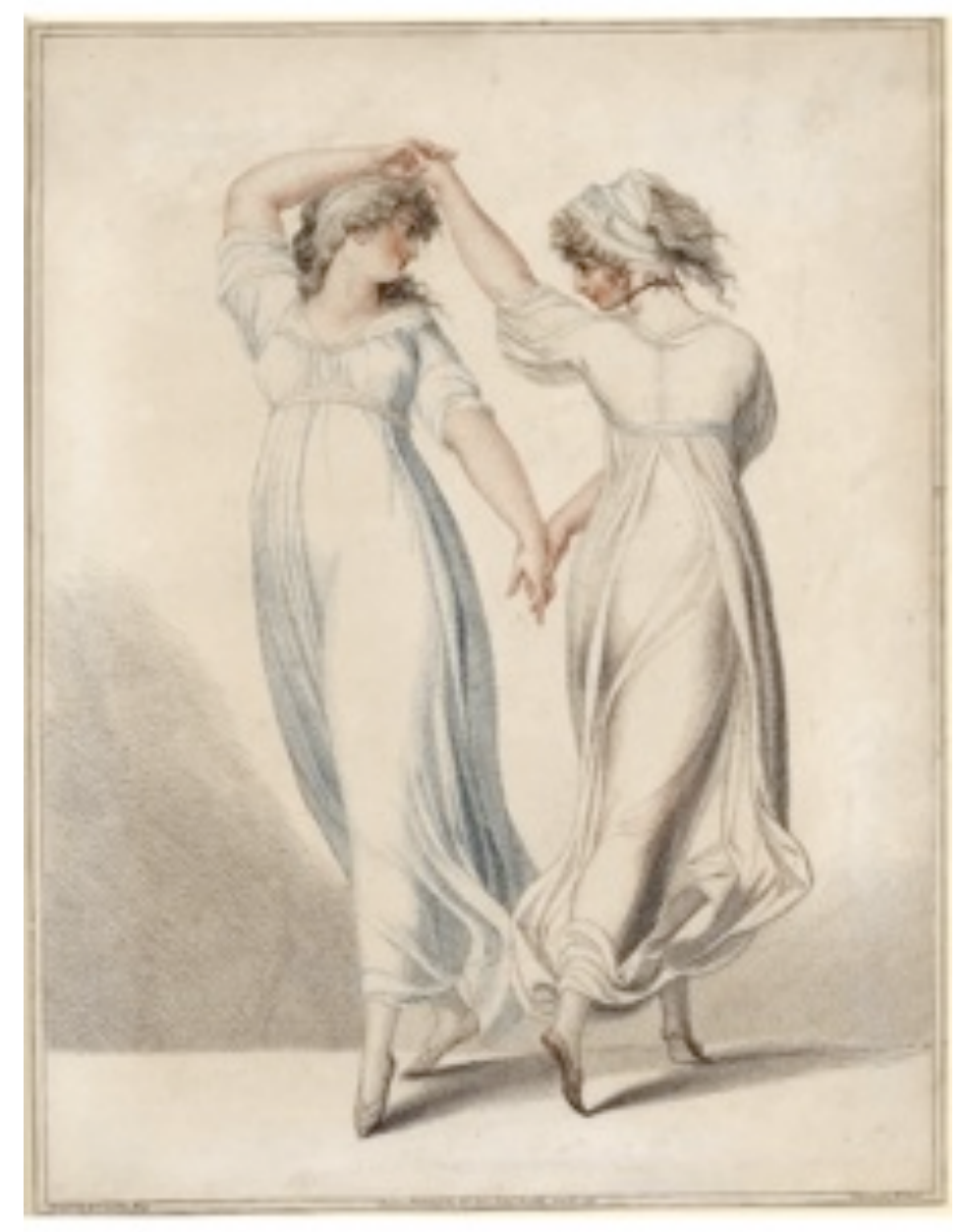

Figure 1: Mariano Bovi, after William Locke, Emma, Lady Hamilton, dancing the tarantella, 1796, stipple printed in colours

(Courtesy: British Museum) 
Though Goethe claimed in his travel journal to have heard the tarantella himself, he made no mention of it in the later publication, the Italian Journey. In all likelihood the journal-distributed among Goethe's friends and acquaintancessubstituted another traveller's account for his own earwitness testimony.38 Certainly, his guide, Johann Volkmann (1732-1803), author of one of the most popular guidebooks of the day, Historisch-kritische Nachrichten von Italien, doubted the authenticity of tarantism and its musical cure. ${ }^{39}$

To recognise in Goethe a tendency to gratify the expectations of the reader by claiming to have heard what was unheard is to acknowledge the difference between the author and the traveller. It is also to recognise a central convention within the travel genre- a tension between credibility and incredulity that extended not only to things seen and felt, but also to things heard. 40

Since aural phenomena are often regarded as transparent forms of historical evidence, Goethe's elaborated and elided remarks on the tarantella and the barcarolle throw up historiographical problems. By exposing the anomalies and disjunctions in his and others' accounts, we recognise the need for an analytic apparatus that acknowledges the ways in which eighteenth-century reporting about music and sound was subject to rhetorical conventions. Investigating what was heard, apparently heard and wilfully or unconsciously unheard is, in other words, a means of simultaneously investigating what was at social and political stake for the traveller and the traveller's audience.

For contemporary scholars then, accounts like Goethe's provide an opportunity to do sound and music history in new ways. Rather than superimposing on the grand tour a typical set of stylistic and aesthetic categories, period groupings and national designations, we can think about eighteenth-century auditory commentary in the same messy terms as its firsthand reporters. If they made things up and heard things that were not there in order to conform to readers' expectations; if their appraisals of French music were tempered more by Rousseau than by their own ears, then they were acting no differently than other, unmusical travellers who matched their accounts of Herculaneum and Pompeii to those in the guidebooks. And, as Charles Dickens' later Pictures from Italy makes clear, by commenting on a broader soundscape grand tourists have bequeathed us the very sound of travel itself: 
You have been traveling along, stupidly enough... and it has become a very jog-trot, monotonous, tiresome sort of business ... [Finally] the first indication of a town appears ... and the carriage begins to rattle and roll over a horribly uneven pavement ... Whip, wheels, driver, stones, beggars, children, crack, crack, crack; helo! hola! charité pour l'amour de Dieu! crick-crack-crick-crack; crick, crick, crick; bump, jolt, crack, bump, crickcrack; round the corner, up the narrow street, down the paved hill on the other side; in the gutter; bump, bump ...41

The grand tour provided an ever-changing sonic backdrop that ran parallel to the more regulated, professionalised appraisal of serious music. And it is here, I think, that we can recuperate something of the lost auditory world of the eighteenth century-one that recovers both its music and its sounds; here that we find an echo of the musical past awaiting its reconstruction. ${ }^{42}$ William Hogarth (1697-1764), that trenchant commentator of mid eighteenth-century life, provides us with an indication of what such wide-ranged listening might entail (see Figure 2, below).

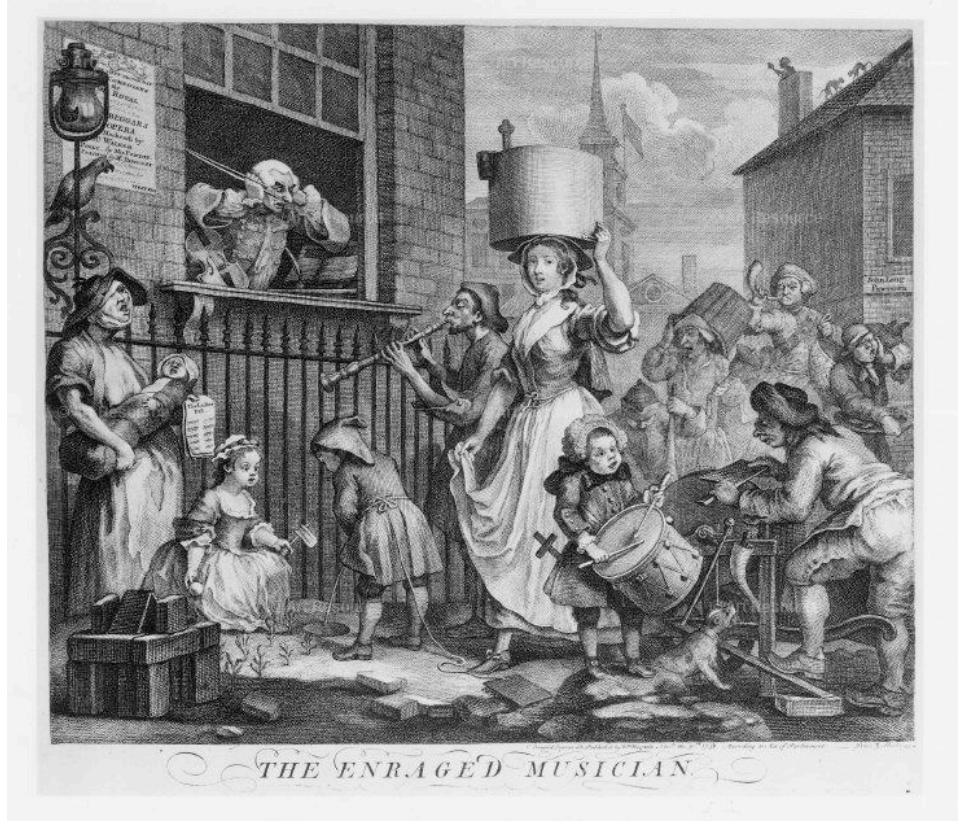

Figure 2: William Hogarth, The Enraged Musician, ca. 1741, etching and engraving on paper (Courtesy: Victoria and Albert Museum, London, Great Britain. Photo credit: V\&A Images, London / Art Resource, New York) 
Hogarth's Enraged Musician, in effect, returns us to London at the end of our Italian grand tour. The cacophony we meant to escape by touring the Continent awaits us at the point of origin. Gritty and unprettified, Hogarth presents us with the complex soundscape of modern life. 43

The engraving offers more than a straightforward commentary on the material conditions of musical life in the eighteenth century. It may also be seen as a metaphor for aesthetic discourses, and hence as a window into eighteenth-century ideas about the nature and purpose of music and sound. Hogarth's scene demonstrates a kind of democratisation of sound production, for everyone, even the baby, is able to participate in this sonic marketplace. In contrast to an earlier age when musicians and musical genres were the preserve of specific times, places and occasions, we now find a breakdown in the hierarchical ordering of music that constitutes a collapse in the sonic ancient regime. In this new economy, it is the serious musician who struggles to find a place where his music will be valued and the distinctions between performer and listener nicely preserved. The musician must compete with tooting and screeching for his livelihood and secure a privileged space in which to practice his art. While he objects to the encroachments on his domain, he has no avenue of aesthetic recourse. Indeed, there is no audience for his tirade because in this musical free-for-all, the nature of music itself is open to question.

Music has become subject to the market's 'invisible hand', as well as its 'invisible ear'. In this riot of sound, music is cleaved from its purpose. The baby is not lulled by its mother's song; the ballad conveys no moral; goods can neither be sold nor animals herded by the street vendors' calls. Instead we are presented with a musical dystopia, where each sound-maker remains isolated within his or her own aural realm. Only the milkmaid crying her wares seems to be exempt from this. Her song, like her gaze, is directed out of the frame of the picture, extending an invitation to participate in the communicative potential of sound and music. We must become the scene's invisible listeners and must listen in new ways as we attempt to reconstruct the soundscape of an earlier age. 
Vanessa Agnew is an associate professor in German Studies at the University of Michigan, working on the cultural history of music, travel, reenactment, and the history of science. She is author of Enlightenment Orpheus: The Power of Music in Other Worlds (2008), winner of the Oscar Kenshur Prize for 18th-Century Studies and the American Musicological Society's Lewis Lockwood Award. She is also a coeditor of Settler and Creole Reenactment (with Jonathan Lamb, 2010), special issues of Rethinking History and Criticism and book series Historical Reenactment and Music in Society and Culture. Agnew is the recipient of fellowships from the National Maritime Museum, Humboldt Foundation, Australian National University, DFG, DAAD, and the American Philosophical Society; she is currently completing a BSc in Natural Science at the Open University.

\section{-NOTES}

1 On Goethe and music, see Günter Hartung, 'Musik', in Bernd Witte (ed.), Goethe Handbuch in vier Bänden, vol. 4. 2, Stuttgart, Weimar, 1998, p. 723-9; Norbert Miller, Die ungeheure Gewalt der Musik. Goethe und seine Komponisten, Hanser, Munich, 2009; Andreas Ballstaedt, Ulrike Kienzle et al. (eds), Musik in Goethes Werk. Goethes Werk in der Musik, Edition Argus, Schliengen, 2003; Lorraine Byrne Bodley, Goethe and Zelter: Musical Dialogues, Ashgate, Farnham, 2009; and Claus Canisius, Goethe und die Musik, Piper, Munich, 1998. On Goethe, music and Italy see Tilman Seebass, 'Idyllic Arcadia and Italian Musical Reality: Experiences of German Writers and Artists (1770-1835)', Imago Musicae: International Yearbook of Musical Iconography, vol. 7, 1990, pp. 149-87; Sousuke Chujo, 'Goethes Musikerlebnis in Italien', Doitsu Bungaku, vol. 18, 1957, pp. 18-25.

2 On Goethe as a 'travel companion', see Julius Haarhaus, Auf Goethes Spuren in Italien, Naumann, Leipzig, 1896-97; Georg von Graevenitz, Goethe unser Reisebegleiter in Italien, Mittler und Sohn, Berlin, 1904, cited in Kelly Barry, 'On Site: Pilgrimage and Authorship in Goethe's “Third Pilgrimage” and Italian Journey' in Writing Travel, ed. John Zilcosky University of Toronto Press, Toronto, 2008, pp. 5778; and Helmuth Wolff, 'Wie Goethe reiste', in Wissenschaftliche Zeitschrift der Martin-LutherUniversität Halle-Wittenberg. Gesellschafts- und sprachwissenschaftliche Reihe, vol. 5, no. 6, 1955/56, pp. 967 et seq. On music on the grand tour see D. Fabris and M. K. Murata (eds), Passaggio in Italia: Music on the Grand Tour in the Seventeenth Century, Brepols, Turnhout,. 3 See Vanessa Agnew, Enlightenment Orpheus: The Power of Music in Other Worlds, Oxford University Press, Oxford, 2008, pp. 29-31.

${ }^{4}$ Here, and in subsequent notes, the quotes in English translation are from the Penguin edition of Goethe's Italian Journey, trans. W. H. Auden and Elizabeth Mayer, London 1962, p. 259. 'Die Urpflanze wird das wunderlichste Geschöpf von der Welt, um welches mich die Natur selbst beneiden soll. Mit 
diesem Modell und dem Schlüssel dazu, kann man alsdann noch Pflanzen ins Unendliche erfinden, die konsequent sein müssen, das heißt: die, wenn sie auch nicht existieren, doch existieren könnten und ... eine innerliche Wahrheit und Notwendigkeit haben.' Goethe, Italienische Reise, in Sämtliche Werke, vol. 15, ed. Andreas Beyer and Norbert Miller, Hanser, Munich, 1992, p. 394.

${ }^{5}$ Goethe, Italian Journey, p. 25. 'Gute Birnen hab' ich gespeist, aber ich sehne mich nach Trauben und Feigen.' Goethe, Italienische Reise, p. 11.

6 Goethe, Italian Journey, p. 259; Goethe, Italienische Reise, p. 368.

${ }^{7}$ Goethe, Italian Journey, p. 24; Goethe, Italienische Reise, p. 11.

8 Goethe, Italian Journey, p. 29; 'Sie trügen ihren Barometer mit sich, und das sei die Harfe. Wenn sich der Diskant hinaufstimme, so gäbe es gutes Wetter, und das habe er heute getan.' Goethe, Italienische Reise, p. 15.

${ }^{9}$ Goethe, Italian Journey, p. 60; 'Nachts geht nun das Singen und Lärmen recht an. Das Liedchen von Marlborough hört man auf allen Straßen, dann ein Hackebrett, eine Violine. Sie üben sich alle Vögel mit Pfeifen nachzumachen. Die wunderlichsten Töne brechen überall hervor.' Goethe, Italienische Reise, p. 57.

10 Goethe, Italienische Reise, p. 91; On the 'nordische[n] Flüchtling', see Goethe, Italienische Reise?, p. 98. On his attention to ambient noise, see for example, his description of the Quacqueri: 'Sie machen gewöhnlich einen steifen tiefen Bückling, und ihre Freude, besonders wenn sie sich einander begegnen, geben sie dadurch zu erkennen, daß sie mit gleichen Füßen mehrmals gerade in die Höhe hüpfen und einen hellen, durchdringenden, unartikulierten Laut von sich geben, der mit den Konsonanten brr verbunden ist.' Goethe, Italienische Reise, p. 582.

11 Jutta Birmele, 'Making Sense of National Stereotyping: Two New Comparative Studies', EighteenthCentury Studies, vol. 35, no. 4, 2002, pp. 642-4. On the eighteenth-century apodemic and musical travel, see Agnew, Enlightenment Orpheus, pp. 47-8.

12 Charles Burney, The Present State of Music in Germany, The Netherlands, and United Provinces. Or, The Journal of a Tour through those Countries, undertaken to collect Materials for A General History of Music, vol. 1, T. Becket, J. Robson; and G. Robinson, London, 1773, pp. iii-vi; Agnew, Enlightenment Orpheus, p. 30.

13 Anonymous, 'Briefe über das Reisen', Der Teutsche Merkur 1, 1785, pp. 3-6.

14 On recent work in this area, see Christian Thorau, 'Listening as Travelling. Spielarten des touristischen Hörens', presented at the Art of Listening: Trends und Perspektiven einer Geschichte des Musikhörens conference, Radialsystem V, Berlin, 13 July 2012.

15 On the sites and activities associated with the Grand Tour, see Jeremy Black, Italy and the Grand Tour, Yale University Press, New Haven and London, 2003.

16 Nino Pirrotta, Pierluigi Petrobelli, 'Italy: Art Music', New Grove Online,

<http://www.oxfordmusiconline.com.proxy.lib.umich.edu/subscriber/article/grove/music/40063pg1

$>$ (accessed March 2012). 
17 Charles Burney, A General History of Music from the Earliest Ages to the Present Period, vol. 1, London, 1776.

18 Wolfgang Gratzer, 'Ist Musikhören (k)eine Kunst?', presented at the Art of Listening: Trends und Perspektiven einer Geschichte des Musikhörens conference,, Radialsystem V, Berlin, 12 July 2012. 19 William Beckford, Dreams, Waking Thoughts, and Incidents, London, 1783, p. 2.

20 Goethe, Italian Journey, p. 259; 'Gestoet war mein guter poetischer Vorsatz, der Garten des Alcinous war verschwunden, ein Weltgarten hatte sich aufgetan.' Goethe, Italienische Reise, p. 327.

21 'Warum sind wir Neueren doch so zerstreut, warum gereizt zu Forderungen, die wir nicht erreichen noch erfüllen können!', Goethe, Italienische Reise, p. 327.

22 Hagen Schulz-Forberg, Unravelling Civilisation: European Travel and Travel Writing, Peter Lang, Brussels, 2005, p. 187.

${ }^{23}$ Joseph Addison, writing in the first years of the century, referred to it as a 'custom at Venice, which they tell me is particular to the common people of this country, of singing stanzas out of Tasso. They are set to a pretty solemn tune, and when one begins in any part of the Poet, it is odds but he will be answered by some body else that overhears him: So that sometimes you have ten or a dozen in the neighbourhood of one another, taking verse after verse, and running on with the poem as far as their memories will carry them.' Remarks on Several Parts of Italy, T. Walker, London, 1773, p. 69.

${ }^{24}$ Jean-Jacques Rousseau, The Confessions of Jean-Jacques Rousseau, vol. 2, Gibbings, London, 1901, p. 214.

25 Leopold Damrosch, Jean-Jacques Rousseau: Restless Genius, Houghton Mifflin, New York, 2005, pp. 174-5. Goethe reiterated this in Dichtung und Wahrheit.

26 On barcarolles in opera, see Giovanni Paisiello, Il Re di Venezia; in piano music, see James Anor Margetts, 'Echoes of Venice: The Origins of the Barcarolle for Solo Piano', DMA thesis, University of Cincinnati, 2008. See also operatic barcarolles in Weber's Oberon (1826), Auber's Fra Diavolo (1830), Verdi's Otello (1887), and Offenbach's Les Contes d'Hoffmann (1881); and for piano-Mendelssohn's Lieder ohne Worte, op. 19 no. 6, Chopin's Barcarolle in F\#, op. 60 (1845-6), and Fauré's 13 barcarolles composed between 1880 and 1921. Maurice J.E. Brown and Kenneth L. Hamilton. 'Barcarolle', Grove Music Online. Oxford Music Online,

<http://www.oxfordmusiconline.com.proxy.lib.umich.edu/subscriber/article/grove/music/02021> (accessed 27 March 2012).

27 Goethe, Italienische Reise, p. 99.

${ }^{28}$ Goethe, Italian Journey, p. 92; 'Wenn der Hörer alsdann zwischen beiden steht, so ist er am rechten Flecke ... Als Stimme aus der Ferne klingt es höchst sonderbar, wie eine Klage ohne Trauer, es ist darin etwas unglaubliches, bis zu Tränen rührendes.' Goethe, Italienische Reise, p. 100.

29 'Menschlich aber und wahr wird der Begriff dieses Gesanges, lebendig wird die Melodie, über deren tote Buchstaben wir uns sonst den Kopf zerbrochen haben. Gesang ist es eines Einsamen in die Ferne und Weite, damit ein anderer, gleichgestimmter, höre und antworte.' Goethe, Italienische Reise, p. 100. 
30 Hester Piozzi: Observations and Reflections Made in the Course of a Journey through France, Italy, and Germany, London, 1789, p. 123. See James Lowry Clifford and Margaret Anne Doody, Hester Lynch Piozzi (Mrs Thrale), Oxford University Press, Oxford, 1987, p. 72. I am indebted to Pierpaolo Polzonetti for drawing my attention to this material in his paper, 'Burney's Fieldwork as a Musical Tourist: Tartini and the "Aria del Tasso,"' presented at the Charles Burney, Musical Travel, and the Invention of Music History Conference, Cornell University, 12-14 March 2010.

31 Charles Burney, A General History of Music, vol. 4, London, 1789, p. 568. For recordings, see the Venetian gondoliers' songs, 'Per pieta del mio tormento' and 'Si la gondola avere', sung by Alasdair Elliott and Harry Nicollon the CD The Grand Tour: Musical Delights Encountered by the 18th-Century Traveller in Paris, Rome, Naples and Venice, Janiculum Recordings, 1999. The first song is from a publication by Adamo Scola published in 1741; the second song-a fifteenth-century text set to an eighteenth-century melody—was published in a collection of Venetian ballads in 1757.

32 See Friedrich Riedel, 'Italienische Musik im Spiegel von Reiseberichten der Goethezeit', in Joseph Martin Kraus und Italien: Beiträge zur Rezeption italienischer Kultur, Kunst und Musik im späten 18. Jahrhundert, Katzbichler, München, Salzburg, 1987, pp. 35-46.

33 'Der Tanz, welcher die Tarantelle genannt wird, ist in Neapel unter den Mädchen der geringsten und Mittelklasse allgemein. Es gehören wenigstens drei dazu: die Eine schlägt das Tamburin, und schüttelt von Zeit zu Zeit die Schellen ... die andern beiden mit Kastagnetten in den Händen machen die Schritte des Tanzes.' Goethe, 'Auszüge aus einem Reise-Journal', in Sämtliche Werke nach Epochen seines Schaffens, vol. 3., no. 2, ed. Karl Richter in cooperation with Herbert G. Göpfert, Norbert Miller und Gerhard Sauder, Hanser, Munich, 1990, pp. 213-14.

34 Stephen Storace, 'A Genuine Letter from an Italian Gentleman Concerning the Bite of the Tarantula', in The Gentleman's Magazine, September 1753, pp. 433-4. On tarantism, see Jean Fogo Russell, 'Tarantism', Medical History, vol. 23, 1979, pp. 404-25; and on the tarantella, see Erich Schwandt, 'Tarantella', Grove Music Online. Oxford Music Online,

<http://www.oxfordmusiconline.com.proxy.lib.umich.edu/subscriber/article/grove/music/27507> (accessed 27 March 2012).

35 A.F. Büsching, 'Schreiben an Professor Kästner, von denen, die von den Taranteln gebissen seyn sollen, [Göttingen, 20 Nov. 1754]' in Hamburgisches Magazin, vol. 14 (1755), p. 433. See, too, [A. Z., trans. C. D.]: 'Die Wirkungen des Bisses der Tarantel, und die Heilungsart derselben durch die Musik sind so wunderbar, dass viele an der Wahrheit der Nachrichten davon gezweifelt haben. Sie sind auch mit solchen allgemeinen Umständen erzählet worden, dass sie, weil ihnen die besondern Umstände, welche nöthig sind, sie von verschiedenen Zufällen zu unterscheiden, gefehlet haben, nicht oft durch die Stärke beystimmender Zeugnisse sind bestätiget worden. Dieser Ursache wegen war ich mit der Nachricht sehr zufrieden, welche aus einem Briefe eines italienischen Herrn in ihrem Magazin... ist abgedruckt worden...' 'Ein Brief an den Herausgeber des Gentleman's Magazine. Aus dem Stück für den Monat Februar 1754', in Hamburgisches Magazin, vol. 14, 1755, p. 89. 
${ }^{36}$ Charles Burney, Italian Tour: The present state of music in France and Italy: or, the journal of a tour through those countries, undertaken to collect materials for a general history of music, T. Becket and Co., London, 1771, p. 255. On the Neapolitan physician Francesco Serao, see David Gentilcore, 'Ritualized Illness and Music Therapy: Views of Tarantism in the Kingdom of Naples', in The History of Music Therapy since Antiquity, ed. Peregrine Horden, Ashgate, Aldershot, 2000, pp. 265-66. For a recording of a Neapolitan tarantella for harpsichord by an anonymous composer, see The Grand Tour, 1999.

37 Add. 31,760. Liner notes, The Grand Tour.

38 After having described the tarantella, Goethe references another travel writer: 'Über beides hat uns Herr von Riedesel in seinen Reisen schöne, genaue Beobachtungen gegeben.' Goethe, Auszüge aus einem Reise-Journal, p. 213.

39 Johann Jacob Volkmann, Historisch-kritische Nachrichten von Italien, Caspar Fritsch, Leipzig, 177072.

40 Gretchen L. Hachmeister, Italy in the German Literary Imagination: Goethe's 'Italian Journey' and Its Reception by Eichendorff, Platen and Heine, Camden House, Rochester, 2002.

41 Charles Dickens, Pictures from Italy, Bernhard Tauchnitz, Leipzig, 1846, pp. 9-10, quoted in Barbara Korte, 'Chrono-Types: Notes on Forms of Time in the Travelogue', in Writing Travel: The Poetics and Politics of the Modern Journey, ed. John Zilcosky, University of Toronto Press, Toronto, 2008, p. 43. 42 Vanessa Agnew, 'Editorial', Eighteenth-Century Music 6, no. 2, 2009, 159-60.

${ }^{43}$ My interpretation of Hogarth's image is indebted to Jeremy Barlow, The Enraged Musician: Hogarth's Musical Imagery. Ashgate, Burlington, 2005. See also Werner Busch, 'Kakophanie! William Hogarth's Enraged Musician', in Musik im sozialen Raum: Festschrift für Peter Schleuning zum 70. Geburtstag, Munich: Buch\&amp, 2011; Joachim Möller (ed.), Hogarth in Context: Ten Essays and a Bibliography, Jonas, Marburg, 1996; and Richard Leppert, Music and Image: Domesticity, Ideology and Socio-Cultural Formation in Eighteenth-Century England, Cambridge University Press, Cambridge, 1994. On reconstructing an historical soundscape, see Charles Knight: 'It is easy to form to ourselves a general idea of the hum and buzz of the bees and drones of this mighty hive, under a state of manners essentially different from our own; but it is not so easy to attain a lively conception of the particular sounds that once went to make up this great discord, and so to compare them in their resemblances and their differences with the roar which the great Babel now "sends through all her gates". We propose, therefore, to put before our readers this passage of Jonson's comedy [The Silent Woman, "a comedy which presents to us a more vivid picture ... of the characteristic noises of the streets of London more than two hundred years ago"]; and then, classifying what he describes, illustrate our fine old dramatic painter of manners by reference to other writers, and by the results of our own observation.' 'Street Noises', London, ed. Charles Knight, London, 1841, p. 129. 